\title{
SURVIVAL AND CONJUGAL TRANSFER BETWEEN BACILLUS THURINGIENSIS STRAINS IN AQUATIC ENVIRONMENT
}

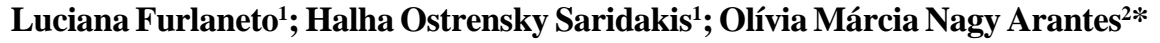 \\ ${ }^{1}$ Departamento de Microbiologia, Universidade Estadual de Londrina, Londrina, PR, Brasil. \\ ${ }^{2}$ Departamento de Biologia Geral, Universidade Estadual de Londrina, Londrina, PR, Brasil.
}

Submitted: March 26, 1999; Approved: November 07, 2000

\begin{abstract}
Field and laboratory studies were conducted to assess the survival of cells and spores and plasmid transfer between Bacillus thuringienis strains in aquatic environment. Results indicated that cells and spores of $B$. thuringiensis can survive for 10 days in water, without altering their number. The sporulation process began after 12-15 hours of inoculation of water. B. thuringiensis was able to transfer conjugative plasmids in the aquatic environment.
\end{abstract}

Key words: Bacillus thuringiensis, conjugation, microbial ecology

\section{INTRODUCTION}

Bacillus thuringiensis $\delta$-endotoxins are recognized safe biological insecticidal proteins. The insecticidal protein gene is usually found in large self-transmissible plasmids $(7,26)$. The commercialized products are generally composed of spore-crystals, and large amounts of such product have been applied to aquatic environment in order to control disease vector flies.

The interest in the fate, survival and conjugation potential of bacteria introduced in field is increasing due to the risks to the environment in consequence of the unwanted release of biological control microorganisms. The ecological significance and importance of environmental gene transfer and survival of cells and spores of biological control microorganisms have been relatively poorly understood.

Many studies have been conducted on plasmid transfer in environmental conditions using Pseudomonas spp $(3,23)$. However, few studies have examined the environmental transfer among $B$. thuringiensis strains. For $B$. thuringiensis, it has been shown that, after having grown in mixed cultures with other Bacillus, the large plasmids, encoding insecticidal toxins, were transferred by a conjugation-like process $(6,7)$. Mating between strains of $B$. thuringiensis, $B$. cereus and $B$. anthracis have been reported involving transference of small and large plasmids $(4,13)$.

In soil microcosm the conjugation-like process has been poorly described $(9,24)$ and no studies have been conducted in aquatic environment. Some information about persistence and survival of $B$. thuringiensis has been documented in soil. Saleh et al. (20) recovered B. thuringiensis from soil 14 to 40 days after the field aplication, and Pruett et al. (19) found spores after 6 months. Saleh et al. (20) showed germination of spores, when incubated in suplemented soil.

Studies conducted in non-suplemented soil indicated a decrease in the number of cells, and the maintenance in spore form (25). Laboratory studies indicate that spores of $B$. thuringiensis var kurstaki can survive for relatively long period in fresh water and marine environment (17).

The aim of this study was to determine the extent of conjugal transfer between $B$. thuringiensis strains in liquid broth, tap water, lake water, and sewage water in both laboratory and field conditions, and to describe the survival of cells and spores of this bacterium under the same conditions.

\footnotetext{
* Corresponding author. Mailing address: Departamento de Biologia Geral, Universidade Estadual de Londrina, CEP 86051-970, Londrina, PR, Brasil. Fax: (+5543) 328-3343. E-mail: arantes@uel.br
} 


\section{MATERIALS AND METHODS}

\section{Bacterial strains}

The strains of $B$. thuringiensis used in this study are listed in Table 1. B. thuringiensis var kurstaki $\mathrm{KT} 0\left(\mathrm{pHT} 73-\mathrm{Em}^{\mathrm{R}}\right)$ harbors the $75 \mathrm{~kb}$ pHT73-Em ${ }^{\mathrm{R}}$ plasmid, which encodes the erythromycin resistence and the Cry1Ac toxin.

Strain 407-1 is an acrystaliferous brown pigment-producing derivative of strain 407 selected by streptomycin resistance. Acrystaliferous fenotype (407-1 and 4Q2-81R) was obtained by $42^{\circ} \mathrm{C}$ treatment.

\section{Mating in liquid broth}

$\mathrm{KT} 0\left(\mathrm{pHT} 73 \mathrm{Em}^{\mathrm{R}}\right)$ was used as the donor strain and either 407-1 or 4Q2.81R were used as the recipient strains. Donor and recipient cells were grown in Luria Bertani broth - LB (21) at $30^{\circ} \mathrm{C}$, with aeration to logarithmic growth phase $\left(10^{7} \mathrm{cfu} \cdot \mathrm{ml}^{-1}\right)$. Enumeration of donor and recipients strains was done by plating on LB agar with appropriate antibiotic. Equal amounts of donor and recipient cells $(250 \mu \mathrm{l})$ were combined in $7 \mathrm{ml}$ of prewarmed $\mathrm{LB}$ broth, and incubated at $30^{\circ} \mathrm{C}$ with shaking at $40 \mathrm{rpm}$ (1). After 2 hours, $100 \mu$ lof the mixture was inoculated onto LB agar plates containing $10 \mu \mathrm{g} \cdot \mathrm{ml}^{-1}$ erythromycin and $200 \mu \mathrm{g} \cdot \mathrm{ml}^{-1}$ streptomycin. The frequencies of conjugation were calculated through the number of exconjugants per number of recipients.

\section{Mating on nitrocellulose membrane filters}

For mating on filters, donor and recipient cells $\left(10^{7} \mathrm{cfu} . \mathrm{ml}^{-1}\right)$ were mixed at the same ratio and filtered through a $0.45 \mu \mathrm{m}$ pore-size nitrocellulose membrane. Filters were placed, bacteria side up, on the surface of LB agar plates and incubated for 2 hours at $30^{\circ} \mathrm{C}$. The cells were eluted from the filters and resuspended in saline solution, and inoculated on LB selective agar plates (16).

\section{Mating in laboratory conditions}

Matings were conducted in tap water, lake water and sewage water. Water samples from different sources were sterilized by autoclaving at $121^{\circ} \mathrm{C}$ for 1 hour. Donor and recipient cells were grown separatelly to logarithmic phase in $10 \mathrm{ml}$ of LB broth, centrifugated and resuspended to the volume of $10 \mathrm{ml}$ of water $\left(10^{8} \mathrm{cfu} \cdot \mathrm{ml}^{-1}\right)(18)$. The total volume of the mixture was incubated at $30^{\circ} \mathrm{C}$ for 24 hours with shaking at $40 \mathrm{rpm}$. Following the incubation, hourly samples were plated on LB agar plates containing erythromycin and streptomycin.

\section{Mating in field conditions}

Cells for mating in field conditions were prepared in the same manner as those for mating in laboratory conditions. The resuspended cells were placed in dialysis bags $\left(\operatorname{Sigma~}^{\circ}{ }^{\circ} 250\right.$ $7 \mathrm{U} ; 10 \mathrm{~cm}$ length, molecular weight cutoff $>12,000)$, each one containing $10 \mathrm{ml}$ of the mixture of cells. The dialysis bags were placed in a sewage lake (22). After 2, 4, 6 and 24 hours, baterial cells were recovered from each bag by removing $1 \mathrm{ml}$ aliquots, following proper dilution and plating onto selective LB agar and incubated at $30^{\circ} \mathrm{C}$.

\section{Plasmid stability}

To determine the stability of plasmid pHT73 in broth medium, culture of exconjugant originated from KT0 $\left(\mathrm{pHT} \mathrm{H} 3 \mathrm{Em}^{\mathrm{R}}\right) / 407-1$ cells were kept exponentially growing by dilutions every 12 hours up to 48 hours, in prewarmed LB broth without antibiotics. Every 12 hours, serial dilutions in saline solution were spread on agar plates without antibiotics. After overnight incubation at $30^{\circ} \mathrm{C}, 100$ individual colonies from exconjugant strain were transferred with a toothpick to agar plates containing erythromycin and streptomycin (15). The plasmid stability in water was calculated by adding exconjugant cells in water samples from different sources, and proceding as described above.

\section{Cell survival study}

The experiments were conducted in the laboratory and in the field using the following types of water: sterile tap water, sterile lake water, sterile sewage and sewage water in field conditions. Strains 4Q2.81R and KT0 $\left(\mathrm{pHT} \mathrm{HEm} \mathrm{Em}^{\mathrm{R}}\right)$ were used.

The cell culture was grown in $50 \mathrm{ml} \mathrm{LB}$ broth at $30^{\circ} \mathrm{C}$, with aeration, to logarithmic phase, centrifugated and washed twice in saline solution. Final concentrated cell suspensions (approximately $10^{8} \mathrm{cfu} \cdot \mathrm{ml}^{-1}$ ) were inoculated into flasks with $50 \mathrm{ml}$

Table 1. Characteristics of $B$. thuringiensis strains used in mating and survival studies.

\begin{tabular}{|c|c|c|}
\hline kurstaki KT0 $\left(\mathrm{pHT} 73 \mathrm{Em}^{\mathrm{R}}\right)$ & $\mathrm{Cry}^{+} \mathrm{Em}^{\mathrm{R}}$ & Vilas Bôas et al. (24) \\
\hline israelensis 4Q2-81R & Cry $^{-} \mathrm{Sm}^{\mathrm{R}}$ & This study \\
\hline
\end{tabular}

$\mathrm{Cry}^{+}$: crystaliferous; Cry- : acrystaliferous; $\mathrm{Em}^{\mathrm{R}}$ : erythromycin resistance; $\mathrm{Sm}^{\mathrm{R}}$ : streptomycin resistance. 
of water, and incubated at $30^{\circ} \mathrm{C}$, with aeration. For cell enumeration, aliquots of $1 \mathrm{ml}$ were withdrawn from each flask at intervals of 24 hours during 10 days, diluted and plated before and after heat treatment $\left(70^{\circ} \mathrm{C}\right.$ for 20 minutes $)$ onto agar $\mathrm{LB}$, and incubated at $30^{\circ} \mathrm{C}$.

For the field study, dialysis bags containing $10 \mathrm{ml}$ of resuspended vegetative cells (as described above) were placed in sewage water. At the time of 1, 2, 6, 8 and 10 days, a dialysis bag was removed and submitted to enumeration of bacteria using selective LB agar.

\section{Spore survival study}

The experiments were conducted in the laboratory using sterile tap, lake and sewage water.

The strains of $B$. thuringiensis were grown in $50 \mathrm{ml}$ of Bacto Peptone broth - BP (14) for 3 days or up to total sporulation of the cells. The culture was heated for $20 \mathrm{~min}$ at $70^{\circ} \mathrm{C}$. The spores were harvested by centrifugation, washed three times in saline solution and resuspended in sterile water to a final volume of $50 \mathrm{ml}$ and incubated at $30^{\circ} \mathrm{C}$ with aeration. For enumeration of spores, water samples $(1 \mathrm{ml})$ were taken every 24 hours up to 10 days, diluted and plated onto selective LB agar, before and after heat treatment. The plates were incubated at $30^{\circ} \mathrm{C}$.

\section{RESULTS}

\section{Conjugal transfer in broth}

The conjugation potential transfer of the plasmid pHT73 in broth and filter was examined. The transference frequencies estimated after 2 hours of mating are listed in Table 2. After mating, exconjugant cells were selected on plates containing streptomycin and erythromicin followed by microscopic observation of crystal (donor strain phenotype). Exconjugant cells from KT0 $\left(\mathrm{pHT} 73 \mathrm{Em}^{\mathrm{R}}\right)$ donor/407-1 recipient presented a brown pigment (recipient strain phenotype).

Concerning the KT0 $\left(\mathrm{pHT} 73 \mathrm{Em}^{\mathrm{R}}\right) / 4 \mathrm{Q} 2-81 \mathrm{R}$ pair, the frequency of transfer of plasmid pHT73 in filter and in broth medium, after 2 hours, was similar. However, for the pair
KT0 $\left(\mathrm{pHT} \mathrm{E} \mathrm{Em}^{\mathrm{R}}\right) / 407-1$, the frequency was 10 -fold higher in broth medium than in filter.

We also analysed if the exconjugant cells 4Q2.81RT that had gained pHT73 plasmid had become competent plasmid donors, when the recipient cell was the 407-1 strain, in mixed culture. The conjugation was detected but the conjugation frequency could not be determined because of the difficulty of selection.

\section{Conjugal transfer in aquatic environment}

For the experiments in water, in laboratory as well as in environmental conditions, the mating pair $\mathrm{KT} 0\left(\mathrm{pHT} 73 \mathrm{Em}^{\mathrm{R}}\right)$ / 407-1 was used. Matings in tap water, lake water and sewage water conducted in the laboratory showed similar dynamics. The conjugation frequencies increased about 10 times in the three types of water in 6 hours, but in sewage water the conjugation frequencies were always higher (Fig. 1 and Table 3 ). A measure taken after 24 hour, indicated a similar frequency to that measured at time 6 hour. The $\mathrm{pH}$ of sewage water used in these studies varied between 9.0 and 10.0 before sterilization and between 7.0 and 8.0 after sterilization. The concentration

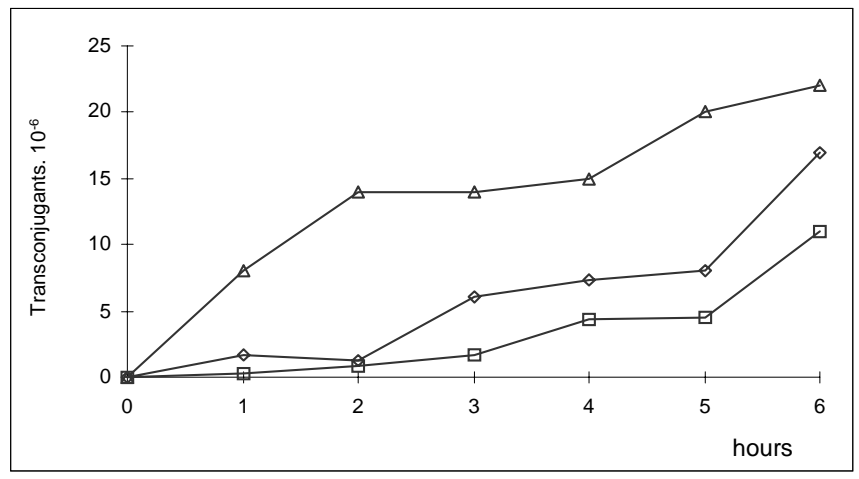

Figure 1. Transfer of plasmid pHT73 from KT0 $\left(\mathrm{pHT} 73-\mathrm{Em}^{\mathrm{R}}\right)$ donor to 407-1 recipient strains in tap water $(\diamond)$, lake water $(\square)$ and sewage water $(\Delta)$ in laboratory conditions.

Table 2. Transfer frequencies between B. thuringiensis strains in broth culture and on nitrocellulose membrane.

\begin{tabular}{|c|c|c|c|}
\hline Donor & Recipient & $\begin{array}{l}\text { Transfer frequencies } \\
\text { (broth mating) }\end{array}$ & $\begin{array}{c}\text { Transfer frequencies } \\
\text { (membrane mating) }\end{array}$ \\
\hline & & 2 hours & 2 hours \\
\hline KT0 $\left(\mathrm{pHT} 73 \mathrm{Em}^{\mathrm{R}}\right)$ & $407-1$ & $1.7 \times 10^{-4}$ & $2.0 \times 10^{-5}$ \\
\hline KT0 $\left(\mathrm{pHT} 73 \mathrm{Em}^{\mathrm{R}}\right)$ & 4Q2-81R & $6.0 \times 10^{-8}$ & $3.0 \times 10^{-8}$ \\
\hline
\end{tabular}

${ }^{1}$ exconjugants per recipient. The values are average of three repetitions. 
Table 3. Transfer frequencies between $\mathrm{KT} 0\left(\mathrm{pHT} 73-\mathrm{Em}^{\mathrm{R}}\right)$ and 407-1 in different sources of water, in laboratory conditions.

\begin{tabular}{lccc}
\hline & & Transfer frequencies $^{1}$ & \\
& 1 hour & 3 hours & 6 hours \\
\hline tap water & $1.6 \times 10^{-6}$ & $6.0 \times 10^{-6}$ & $1.7 \times 10^{-5}$ \\
lake water & $1.2 \times 10^{-6}$ & $2.5 \times 10^{-6}$ & $1.0 \times 10^{-5}$ \\
sewage water & $5.5 \times 10^{-6}$ & $1.4 \times 10^{-5}$ & $2.4 \times 10^{-5}$ \\
\hline
\end{tabular}

${ }^{1}$ exconjugants per recipient. The values, are average of three repetitions.

Table 4. Chemical characteristics of water samples, used in the conjugation experiments

\begin{tabular}{lcccc}
\hline mg. $1^{-1}$ & \multicolumn{4}{c}{ sample } \\
\hline & 1 & 2 & 3 & 4 \\
\hline $\mathrm{Ca}$ & 28.72 & 13.77 & 14.40 & 15.70 \\
$\mathrm{Mg}$ & 3.84 & 4.48 & 4.67 & 3.91 \\
$\mathrm{P}$ & $<0.05$ & 0.11 & 2.22 & 2.88 \\
\hline
\end{tabular}

1 -sterile tap water

2 -sterile lake water

3 -sterile sewage water

4 - non sterilized sewage water

of some ions such as $\mathrm{Ca}, \mathrm{Mg}$, and $\mathrm{P}$, in the three types of water remained the same after sterilization (Table 4).

In field conditions, the maximum and minimum concentration of $\mathrm{O}_{2}$ dissolved in the water was 13.4 and 9.4, respectively. In the period of the experiment the temperature of sewage water varied between 32 to $35^{\circ} \mathrm{C}$. In studies conducted in sewage water, in field conditions, the conjugation frequency detected after 6 hours of experiment was $1 \times 10^{-6}$, and remained constant until 24 hours, which was the last measurement.

The experiments carried out in liquid medium and in water indicated the pHT73 plasmid maintained its stability when in non-selective conditions. The stability was estimated to be $100 \%$.

\section{Survival spore and cell study}

In laboratory the survival of $B$. thuringiensis strains was monitored by counting of viable cells and spores. The sporulation dynamics of $B$. thuringiensis vegetative cells in the different types of water is shown in Fig. 2. In all trials, the numbers of viable cells remained inaltered after inoculation in water. After 24 hours of inoculation in water in laboratory,

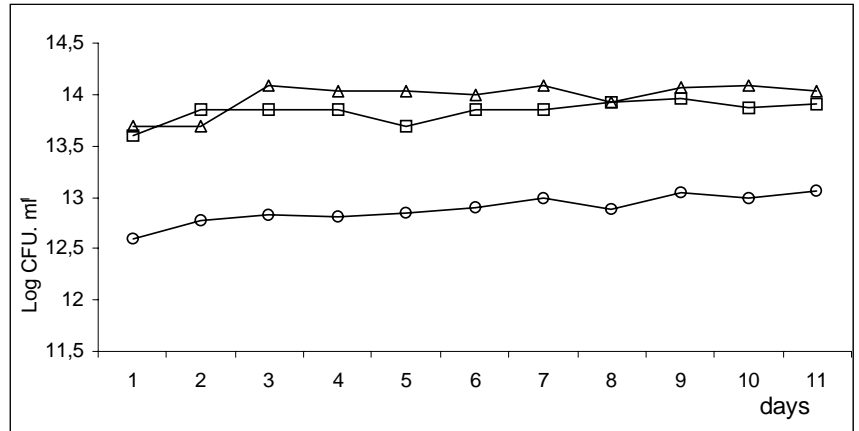

Figure 2. Sporulation of $B$. thuringiensis strains in laboratory conditions. Tap water $(\mathrm{O})$, lake water $(\Delta)$, sewage lake water $(\square)$. Each point corresponds to the average number of spores of strains 4Q2.81R and $\mathrm{KTO}\left(\mathrm{pHT} 73 \mathrm{Em}^{\mathrm{R}}\right)$.

approximadely $100 \%$ of the cells were sporulated, without decrease in this number. Endospores were observed after 8 hours of inoculation, and spores after $12 \mathrm{~h}$ in tap water and 15 in lake and sewage lake water. In the spores survival study, loss of spores or germination were not observed. The number of spores remained stable during the 10 days of experiment (Fig. 2).

In the studies conducted in the field a small decrease in the number of cells of strain $4 \mathrm{Q} 2.81 \mathrm{R}$ was observed after 6 hours of inoculation, and this number did not change in the course of the experiment.

\section{DISCUSSION}

When grown in broth culture, $B$. thuringiensis strains are able to transfer plasmids in variable frequencies by a conjugation-like plasmid transfer process first described by Gonzalez et al. $(7,8,10,15,24)$. In this study, experiments with mating broth using $B$. thuringiensis strains showed frequencies of $10^{-4}$ to $10^{-8}$ (Table 2). These results are in agreement with those observed by other authors. $(2,10,24)$. 
For mating between $\mathrm{KT} 0\left(\mathrm{pHT} 73 \mathrm{Em}^{\mathrm{R}}\right)$ and $4 \mathrm{Q} 2.81 \mathrm{R}$, the lower frequency observed can be attributed to the effect of either bacteriocins $(1,11,12)$ or agregation phenotype between strains $(1,2)$. The method used for mating between this pair did not interfere in the frequency of transference (Table 2).

For the first time the results presented here indicate that plasmid transfer between $B$. thuringiensis strains can occur in aquatic environment both under laboratory and field conditions. It was observed that in the laboratory the conjugation frequency in sewage water was 10-fold higher than in field conditions. Parameters such as temperature, nutrients, and $\mathrm{pH}$ may interfere with gene transfer. Vilas Bôas (25) showed that the acid pH of soil does not alter the conjugation process. In our study, the $\mathrm{pH}$ value ranged from alkaline to neutral condition, and did not hinder the conjugation process.

Our results showed that survival and persistence of $B$. thuringiensis during 10 days in water in laboratory and in field conditions were similar. In field conditions, any contamination of water could be observed because cells and spores were suspended in a dialysis bag and not monitored at the bottom of sewage lake. However, these condition did not show the influence of the aquatic microbial environment. $B$. thuringiensis strains inoculated in water of different origins presented a constant kinetics in spore formation and persistence. In another study (17), a higher percentage of survival of B. thuringiensis in lake water than in tap and distilled water was shown. The authors observed a $40 \%$ decrease in viable cells in the three di treatments in the 10 days of experiment, and they remained relatively stable until the $70^{\text {th }}$ day. In the present study, loss of viable cells was not observed. In field conditions, the basic $\mathrm{pH}$ did not alter the survival of $B$. thuringiensis.

\section{ACKNOWLEDGMENTS}

We thank João de Godoy Bueno for technical assistance and Sérgio Camargo Sisti for secretarial assistance. This work was supported by research funds from Fundação Banco do Brasil and Universidade Estadual de Londrina. L. Furlaneto was supported by a fellowship from CAPES.

\section{RESUMO}

\section{Sobrevivência e conjugação de Bacillus thuringiensis em ambiente aquático}

O presente trabalho é um estudo sobre a sobrevivência e a conjugação de linhagens de Bacillus thuringiensis em água. Os experimentos conduzidos no laboratório mostram que as células e os esporos de B. thuringiensis podem persistir pelo menos 10 dias na água. A esporulação inicia-se 12-15 horas após a inoculação. O processo de conjugação foi demonstrado em diferentes ambientes aquáticos, tanto em condições de laboratório quanto no meio ambiente.

Palavras-chave: Bacillus thuringiensis, conjugação, ecologia microbiana.

\section{REFERENCES}

1. Andrup, L.; Damgaard, J.; Wassermann, K. Mobilization of small plasmids in Bacillus thuringiensis subsp. israelensis is accompanied by specific agregation. J. Bacteriol., 175:6530-6536, 1993.

2. Andrup, L.; Jorgensen, O.; Wilcks, A.; Smidt, L.; Jensen, J. B Mobilization of "nonmobilizable" plasmids by the aggregationmediated conjugation system of Bacillus thuringiensis. Plasmid, 36:1$11,1996$.

3. Bale, M. J.; Fry, J. C.; Day, M. J. Plasmid transfer between strains of Pseudomonas aeruginosa on membrane filters attached to river stones. J. Gen. Microbiol., 133:3099-3107, 1987.

4. Battisti, L.; Green, B. D.; Thorne, B. C. Mating system for transfer of plasmids among Bacillus anthracis, B. cereus and B. thuringiensis. J. Bacteriol., 162:543-550, 1985.

5. Bora, R. S.; Murty, M. G.; Shenbagarathai, R.; Sekar, V. Introduction of a lepdopteran-specific insecticidal crystal protein gene of Bacillus thuringiensis subsp. kurstaki by conjugal transfer into a Bacillus megaterium strain that persistis in the cotton phyllosphere. Appl. Environ. Microbiol., 60:214-222, 1994.

6. Chapman, J. S.; Carlton, B. C. Conjugal plasmid transfer in Bacillus thuringiensis. In: Helinski, D. R.; Cohen, S. N.; Clewell, D. B.; Jackson, D. A.; Hollaender, A. (Eds.). Plasmids in Bacteria. Plenum Publishing Corporation, New York, 1985, p. 453-467.

7. Gonzalez, J.M., Jr; Brown, B.J.; Carlton, B.C. Transfer of Bacillus thuringiensis plasmids coding for d-endotoxin among strains of Bacillus thuringiensis and Bacillus cereus. Proc. Natl. Acad. Sci., 79:6951-6955, 1982.

8. Gonzalez, J.M.; Carlton, B.C. A large transmissible plasmid is required for crystal toxin production in Bacillus thuringiensis variety israelensis. Plasmid, 11:28-38, 1984.

9. Haack, B. J.; Andrews, R. E.; Loynachan, T. E. Tn-916 mediated genetic exchange in soil. Soil Biochem., 28:765-771, 1996.

10. Jarret, P.; Stephenson, M. Plasmid transfer between strains of $B$. thuringiensis infecting Galleria mellonela and Spodoptera littoralis. Appl. Environ. Microbiol., 56:1608-1614, 1990.

11. Jensen, G. B.; Andrup, L.; Wilcks, A.; Smidt, L.; Poulsen, O. M.The aggregation-mediated conjugation system of Bacillus thuringiensis subsp. israelensis: host range and kinetics of transfer. Current Microbiol., 33:228-236, 1996.

12. Jensen, G. B.; Andrup, L.; Wilcks, A.; Petersen, S. S.; Damgaard, J.; Baum, J. A. The genetic basis of the aggregation system in Bacillus thuringiensis subsp. israelensis is located on the large conjugative plasmid pXO16. J. Bacteriol., 177:2914-2917, 1995.

13. Klier, A.; Bourgouin, G.; Rapoport, G. Mating between Bacillus subtilis and Bacillus thuringiensis and transfer of cloned crystal genes. Mol. Gen. Genet., 19:257-262, 1983.

14. Lecadet, M.-M; Blondel, M. D.; Ribier, J. Generalized transduction in Bacillus thuringienisis var berliner 1715, using bacteriophage CP54. Ber. J. Gen. Microbiol., 121:203-212, 1980.

15. Lereclus, D.; Arantes, O. M. N. spbA locus ensures the segregational stability of pHT1030, a novel type of Gram-positive replicon. Mol. Microbiol., 6:35-46, 1992.

16. Lereclus, D.; Menou, G.; Lecadet, M-M. Isolation of a DNA sequence related to several plasmids from Bacillus thuringiensis after a mating involving the Streptococcus faecalis plasmid pAMb1. Mol. Gen. Genet., 191:307-313, 1983.

17. Menon, A. S.; Mestral, J. Survival of Bacillus thuringiensis var. kurstaki in water. Water, Air and Soil Pollution, 25:265-274, 1985. 
18. O'Morchoe, S. B.; Ogunseitan, O.; Sayler, G. S.; Miller, R. V. Conjugal transfer of R68.45 and FP5 between Pseudomonas aeruginosa strains in a freshwater environment. Appl. Environ. Microbiol., 54:1923-1929, 1988.

19. Pruett, C. J. H.; Burges, H. D.; Wyborn, C. H. Effect of exposure to soil on potency ans spore viability of Bacillus thuringiensis. J. Invertebr. Pathol., 35:168-174, 1980.

20. Saleh, S. M.; Harris, R. F.; Allen, O. N. Fate of Bacillus thuringiensis in soil: effect of soil $\mathrm{pH}$ and organic amendment. Can. J. Microbiol., 16:667-680, 1970.

21. Sambrook, J.; Fritsch, E. F.; Maniatis, T. Molecular cloning. A laboratory manual. Cold Spring Harbor Laboratory Press, New York, $1989,545$.

22. Sobecky, P. A.; Schell, M. A.; Moran, M. A; Hodson, R. E. Adaptation of model genetically engineered microrganisms to lake water: growth rate enhancements and plasmid loss. Appl. Environ. Microbiol., 58:3630-3637, 1992.
23. Venables, W. A.; Wimpenny, J. W. T.; Ayres, A.; Cook, S. M.; Thomas, L. V. The use of two-dimensional gradient plates to investigate the range of conditions under which conjugal plasmid transfer occurs. Microbiol., 141:2713-2718. 1995.

24. Vilas Bôas, G. F. L. T.; Vilas Bôas, L. A.; Lereclus, D.; Arantes, O. M. N. Bacillus thuringiensis conjugation under environmental conditions. FEMS Microbiol. Ecol., 25:369-374, 1998.

25. Vilas Bôas, L. A.; Vilas Bôas, G. F. L. T.; Saridakis, H.; Lemos, M. V. F.; Lereclus, D.; Arantes, O. M. N. Survival and conjugation of Bacillus thuringiensis in a soil microcosm. FEMS Micorbiol. Ecol., 31:255259, 2000.

26. Whiteley, H. R; Schnepf, H. E. The molecular biology of parasporal crystal body formation in Bacillus thuringiensis. Ann. Rev. Microbiol., 40:549-576, 1986. 